\title{
Commercial utilization of Allo (Girardinia diversifolia) by the Rais of Sankhuwasabha for income generation
}

\author{
Tanka P Barakoti ${ }^{1}$ and Keshav P Shrestha ${ }^{2}$
}

\begin{abstract}
Studies carried out during 1999 and 2000 on utilization of Allo (Girardinia diversifolia L.) in the eastern hills revealed that traditional knowledge was highly used in developing commercial enterprise of this species. Surveys conducted on various aspects of this species through semi-structured interview identified that Allo has become an established income generating commodity in Bala, Sisuwa, Tamku and Mangtewa VDCs of Sankhuwasabha district.
\end{abstract}

\begin{abstract}
Time line showed that Allo activities were started by Kulung Rais from 1950, but increased after 1993. The community started to make fancy items, such as varieties of bags, jewellery purse to travel bags, coat cloth, and ladies items-shawl, brassier, when the outsiders took interest in Allo products. Dyeing was also practiced according to customers' demand using local plants: Majitho, Banmara, Chutro, Dar. For spinning, bamboo made hand spindle called Katuwa was used (94.8\% respondents). It is handy and easy to spin thread while walking. Weaving was done in locally made wooden handloom. Traditional processing method adopted was: green lokta- drying (2-3 days), boiling with wood ash, washing, drying, dry fibre- mixing with micaceous clay (Kamero). Wood ash was used to boil easily (39\%) and also make the fibre soft (20.8\%). No idea about the use of caustic soda instead of ash. The quantity of ash for one Dharni $(2.5 \mathrm{~kg})$ of lokta varied 4-24 Manas (1 Mana equals about $300 \mathrm{~g}$ ). White clay was used @ $2 \mathrm{~kg}$ for $2.5 \mathrm{~kg}$ dry lokta to make the fibre soft and easy for spinning (62.3\%).
\end{abstract}

Keywords: Allo, Enterprise development,Indigenous knowledge, Rai, Sankhuwasabha.

The Himalayan Giant Nettle, Girardinia diversifolia (Friis, 1981), which belongs to the family Urticaceae, is locally known as Allo in Nepali in the eastern and central regions, and Puwa in the western part of Nepal. There are several vernaculars to name it: Bhangre Sisnu, Lekhko Sisnu, Thulo Sisnu, Potale, Nagai etc (Gurung, 1988). Endemic to Himalayan region, it is one of the historically important nontimber forest products (NTFPs) for Nepal. It grows in the hill districts from east to west between the altitudes of 1200 to 3000 meter and can be found in the tropical areas of Asia and Africa (Friis, 1981, Shrestha and Hoshion, 1998). Its fibre was previously used for weaving coarse cloths to make Dhokro (long sack) for putting grains and flour, fishing net, bag, Namlo (porter's head band for carrying Doko, Dhokro), Damlo (rope for tying cattle, buffalo, goat), Bhangre Topi (cap, hat), etc since generations. Use of Allo fibre had been declining before coming jute, synthetic and other products in the hills. There is a popular proverb in Nepali "Bhangra ko Topi lai Guyenli ko Phool" means good flower on rough cap, i.e. odd or not matching.
Allo is an under-shrub about $1.5 \mathrm{~m}$ to $4 \mathrm{~m}$ tall, armed with stinging hairs. It naturally occurs in forests. The species prefers sparsely shade areas. As a result of increasing pressure of population, its availability is declining, especially at lower altitudes due to destruction of habitat. In Sangkhuwasabha, natural stands are found beyond the normal area of the villages, in remote jungles. According to Sinha (1989) declining trend of Allo in the nearby areas for collection suggests need of planting to meet the increasing demand. As the species is shade loving, cultivation could be combined as an under-storey crop (Singh and Shrestha, 1989).

In the eastern hills, Sankhuwasabha district is well known for Allo product. Rais are famous for weaving Allo cloths (Joshi et al, 1989). Shrestha (1994) reported that 95 percent out of 1029 families in four VDCs were using yarn spun from Allo. They have been extracting bast and spinning fibre to weave fashionable bags, sacks, mats, jackets, porter's headbands, cloths and castanets. Most items are made

\footnotetext{
Senior Scientist (S-4), NARC, ARS Pakhribas, Dhankuta.

2 Technical Officer, NARC, ARS Pakhribas, Dhankuta.
} 
for home use and are sold in Melas, Bazaars at Dingla and Bhojpur (Dunsmore and Dunsmore, 2000). The fashionable items have attracted the tourists and gained popularity.

Changing circumstances led higher demand of fashionable products of Allo. Hence the residents of Sangkhuwasabha started to harvest it extensively for weaving different materials to fulfil outsiders/ tourists' demand. As a result, natural stands have been declining despite the rules and regulation of the forest user groups, as they open for harvesting only from September to December (Shrestha, 2000). The users have been applying local knowledge and implements for processing bast, for spinning and weaving. There is little information on ethno-botany, processing, weaving, marketing, and domestication practices. Therefore identification of the existing situation needed for better planning research and development works, for management and sustainable utilization to meet the increasing demand. In order to make better of the Allo business in a sustainable way, to identify the practices, constraints and opportunities through a study, surveys were planned with the following objectives in the proposed area.

$>$ To understand the existing situation of Alloworks and its utilization

> To verify farmers' knowledge on the Allo growing environment

$>$ To assess local processing techniques and materials for further improvement

\section{Materials of methods}

The study on Allo was conducted through the review of literature and field survey. The literatures available in the concerned libraries of different organizations in Pakhribas, Sankhuwasabha and Kirtipur were consulted. For field study, an exploratory visit of a multidisciplinary team of socio-economist, agronomist, farming system specialist, soil scientist, cottage development specialist, entomologist, and plant pathologist was organized to Allo areas in northern hills of Sankhuwasabha district in 1999. As recommended by the team, a semi-structured questionnaire was developed and pre-tested. Then surveys were conducted in 1999 and 2000 with 77 informants of Bala, Sisuwa, Tamku, and Mangtewa VDCs. These sites were selected based on the literature and information acquired. Studies were undertaken on various aspects of Allo: habitat, types, availability, agro-eco-requirements, socio-economy, cultural value, ratio of green and dry lokta, processing procedure, spinning, weaving, production of different products, use and marketing. The data were analyzed in the SPSS (Statistical Package for Social Science) computer soft ware package.

\section{Result}

\section{Socio-economic value}

It was revealed that Girardinia diversifolia has economic and cultural values for Rai, Gurung, Sherpa, Magar in the hills of Nepal. Kulung Rais use it in their religious ceremonies. They offer Allo cloth to God in their Nagi Puja. They have to wear Bhangra cloth at the entry of new house, and upon demise of a family member. They also present cloth when the daughter gets married. Allo has other values: it is a source of livestock feed, bedding material, fuel-wood (Gibbon et al, 1988) and live fence. Manandhar (1989) reported that decoction from leaf is used to treat headache, joints, and fever. It can be used for making blue dye and paper. The seed containing $10-12 \%$ oil could be used for soap and other oil based industries (Dunsmore and Dunsmore, 2000).

\section{Time line of allo works in the study area}

Utilization of Allo was since generation in Nepal from the early stage of Nepalese civilization. However, the history of Allo works was as early as 2007 BS in the study area i.e. from the advent of democracy. Different informants had started the work at different years (Table 1). Few of them (4 persons) started earlier (2007-2023 BS), some of them (21 persons) during 2024-2040, and most of them (51 persons) started during 2041-2057, the maximum reached in 2050 B.S. The frequency/ percent showed no definite trend of Allo works in the years (Fig. 1).

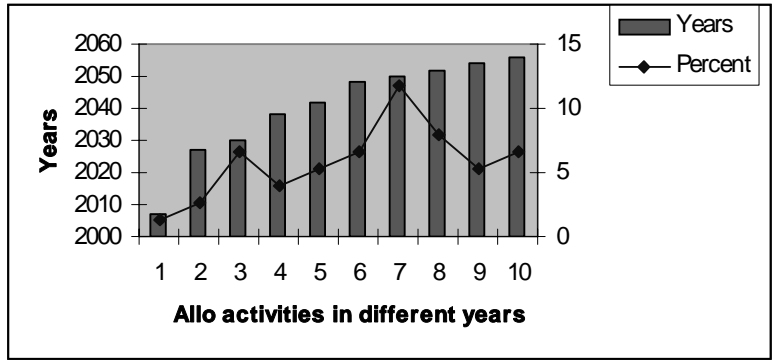

Figure 1: Allo work started by the respondents

\section{Availability and growing}

Allo is known to grow naturally in the middle and high hills partly from east to the west of Nepal. It can be grown up to $3000 \mathrm{~m}$ above sea level however, 
it occurs beneath the forest canopy, mostly between $1500-2500 \mathrm{~m}$. Its availability has been declining with the increasing pressure of population especially at lower altitudes due to the need for tree cover. In Sankhuwasabha, natural stands found in forests are beyond the normal area around villages. In the remoter villages at higher altitudes it is available within day's walking distance.

\section{Habitat: altitude, aspect and soil}

Allo is found from mid hills $(1400 \mathrm{~m})$ and high hills (up to $2500 \mathrm{~m}$ ) areas. The study site lying between this ranges housed different pockets of Allo from thin to dense populations. The natural stands are found commonly grown in relatively moist and shady land, which seems suitable habitat. The pockets located in the community forests of the study area represent it. Allo is therefore available in many parts however, this forest species as a major NTFP is not utilized in other areas like in the study area.

Most of the respondents $(80.6 \%)$ reported that the best altitude for Allo is mid belt of mid to high hills (Table 1). About $15 \%$ mentioned mid altitude and its top region $(2500 \mathrm{~m})$ to be suitable, but they were not confident about the exact altitude. Similarly, the suitable aspect for Allo mentioned by 48.7 per cent informants (Table 2) was west followed by the east $(17 \%)$. Some informal respondents told north facing also to be suitable. As the aspects for Allo vary in other parts of the country, the respondents might have depended just on their locality. Therefore it is difficult to rely on this information only. Study of the aspect in other parts will give clearer picture in this regard. In case of soil type, black and fertile soil is the prerequisite. Above $93 \%$ interviewees (Table 2) expressed the need of black fertile soil, which must be deep and well drained. Brown soil is also okay. Similarly, bank of streamlets is good for better growth.

\section{Collection of bark (Bast)}

Bast is collected from the community forests of each VDC in the study area. Bast collection has become a regular business and this activity is carried in organized manner. Members of the FUGs and VDCs are confined to the concerned community forest for harvesting of Allo. For example, farmers of Bala VDC use Turni, Chhinka villages, and Mudhe and Benchhong villages use Chitre forest. Best time for harvesting is November to December. Collection rule of FUG has been recently adopted. One user should pay NCRs. 15 for a coupon to bring a Bhari (about $30-40 \mathrm{~kg}$ ) load on back from that community forest. The users have to pay double (NRs. 30) per coupon to use other's community forest. Extraction of bark or Lokta from the stem is very tedious and time consuming job. It is hard due to nettle stings in the bark, so thick and hard glove required for warping. The extractors have to spend 3-5 nights in the Allo forest and one can extract $1.5(=3 \mathrm{~kg})$ to 3 Dharni per day. Females are also involved in this work. $44.2 \%$ informants expressed that they not only collect but also buy dry Lokta and threads among each other (Figure 2). Of the respondents, $42.6 \%$ collect green Lokta or bast from the forest. Only $9.1 \%$ purchase yarn for making clothes.

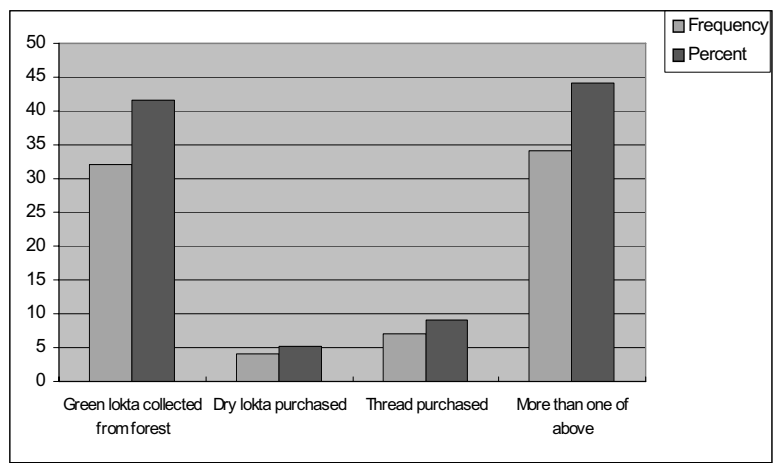

Figure 2: Source of materials used to produce yarn.

Table-1: Altitude, Aspect, and Soil for Allo.

\begin{tabular}{lcclccccc}
\hline \multicolumn{2}{c}{ Altitude } & \multicolumn{1}{c}{ Aspect } & \multicolumn{3}{c}{ Soil } \\
\hline \multicolumn{1}{c}{ Description } & Frequency & $\%$ & Name & Frequency & $\%$ & Type & Frequency & $\%$ \\
\hline Around $2000 \mathrm{~m}$ & 32 & 41.6 & West & 37 & 48.7 & Blackish & 59 & 76.6 \\
$1700-2500 \mathrm{~m}$ & 30 & 39.0 & East & 13 & 17.1 & Fertile black & 13 & 16.9 \\
$1100-1700 \mathrm{~m}$ & 8 & 10.4 & Not known & 9 & 11.8 & Not known & 5 & 6.5 \\
Not known & 4 & 5.2 & North & 6 & 7.9 & - & - & - \\
Around $1700 \mathrm{~m}$ & 3 & 3.9 & North-East & 6 & 7.9 & - & - & - \\
& - & - & North-West & 5 & 6.6 & - & - & - \\
\hline Total & $\mathbf{7 7}$ & $\mathbf{1 0 0}$ & Total & $\mathbf{7 6}$ & $\mathbf{1 0 0}$ & Total & $\mathbf{7 7}$ & $\mathbf{1 0 0}$ \\
\hline
\end{tabular}


Respondents were asked for the time taken to reach Allo growing areas for collection. 39.5\% needed more than 4 hrs.,whereas $24 \%$ requires $1-2$ hrs to reach in the Allo pockets (Figure 3).

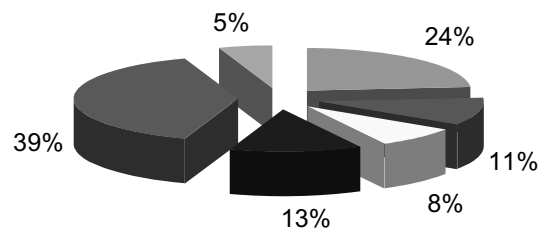

$\square$ 1-2 hrs $\square 1-3$ hrs $2-3$ hrs $\square 2-4$ hrs $\square>4$ hrs $\square$ Not collecting

Figure 3: Time to Reach Allo Pockets from the houses of the Respondents

\section{Shade Requirements}

Allo is a shade loving plant. It can tolerate frost, but may die if frost remains more than 3-4 days. Out of 77 interviewees, $50.6 \%$ mentioned that Allo requires maximum shade, and $31.2 \%$ mentioned optimum requirement (Figure 4).

$51 \%$
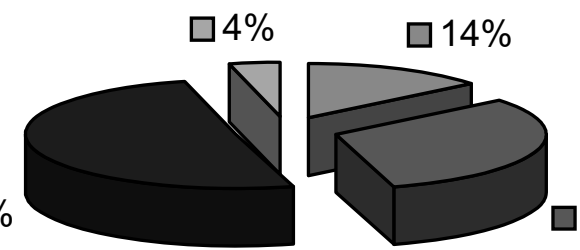

$31 \%$

$\square$ Lesser $\square$ Optimum $\square$ Maximum $\square$ Not required

Figure 4: Shade Requirement for Allo

\section{Ratio of lokta, fibre and thread}

The ratio or proportion of dry bark (Lokta) from green was different as reported by the respondents. The ratio between Jakhilma (Fibre) and bast as well as between thread and Jakhilma is presented (Table $2)$. The farmers use their traditional measuring system, i.e. Dharni and pol, where one Dharni equals about 16 pols $=2.54 \mathrm{~kg}$. The variation might be mainly due to maturity of Allo stem, and time of collection.

\section{Processing}

The villagers/ weavers have been using traditional methods for processing Allo fibre. It follows a number of steps such as drying green Lokta, boiling, washing, drying, mixing with Kamero mato etc. They also mix wood ashes with raw bast while boiling in water. Caustic soda is rarely used. Out of 77 respondents only one used caustic soda. While querying the reason, $84.4 \%$ replied that its use is unknown (Table 3), 13\% mentioned that caustic soda is not available. The green Lokta is dried for 2-3 days during sunny day before boiling.

\section{Use of wood ash}

Ash is the major processing material for cooking Lokta. It is produced from fuel-wood, while cooking food and other product. As the population pressure has been resulting in degradation of the community forest, the quantity of wood ashes required for boiling raw fibre was assessed to examine future sustainability on this product. All the informants anonymously expressed that there was no problem of fuel wood for ash making at present.

The result presented in Table 3 shows various reasons of using ashes, of which most (39\%) replied that it helps to make easy for boiling, whereas $20.8 \%$ said easily to boil as well as make Jakhilma soft for spinning. It also eases to wash the yarn. It requires more ashes taking longer time for boiling. The quantity of ash required for boiling one Dharni of dry Lokta was 2 to 24 Mana (Table 3), where $38.4 \%$ respondents noted 16 Mana, and $24.7 \%$ respondents noted 8 Mana (One Mana is about $250 \mathrm{~g}$ ). The extreme differences need to practically verify.

Table 2: Ratio of Lokta, Jakhilma, and thread from one Dharni (2.5 kg)

\begin{tabular}{|c|c|c|c|c|c|c|c|c|}
\hline \multicolumn{3}{|c|}{ Dry Lokta from $2.5 \mathrm{~kg}$ green Lokta } & \multicolumn{3}{|c|}{ Jakhilma from $2.5 \mathrm{~kg}$ dry Lokta } & \multicolumn{3}{|c|}{ Thread from $2.5 \mathrm{~kg}$ Jakhilma } \\
\hline Ratio & Freq. & $\%$ & Ratio & Freq. & $\%$ & Ratio & Freq. & $\%$ \\
\hline 11 & 24 & 31.6 & 16 & 39 & 51.3 & 8 & 27 & 36.5 \\
\hline 16 & 21 & 27.6 & 8 & 26 & 34.2 & 16 & 26 & 35.1 \\
\hline 8 & 17 & 22.4 & 11 & 3 & 3.9 & 24 & 10 & 13.5 \\
\hline 5 & 8 & 10.5 & 4 & 2 & 2.6 & 4 & 6 & 8.1 \\
\hline 6 & 4 & 5.3 & 14 & 2 & 2.6 & 11 & 4 & 5.4 \\
\hline 4 & 1 & 1.3 & 24 & 2 & 2.6 & 26 & 1 & 1.4 \\
\hline 10 & 1 & 1.3 & 9 & 1 & 1.3 & Total & 74 & 100 \\
\hline Total & 76 & 100 & 26 & 1 & 1.3 & Mean & 14.8 & \\
\hline
\end{tabular}


Table 3: Using ash for boiling dry Lokta and quantity of ash required for $2.5 \mathrm{~kg}$ Lokta.

\begin{tabular}{lccccc}
\hline Reason of ash use & Frequency & $\mathbf{0}$ & Ash (Mana) & Frequency & \% \\
\hline To cook easily & 30 & 39.0 & 10 & 21 & 28.8 \\
To cook easily and make Jakhilma soft & 16 & 20.8 & 7 & 4 & 5.4 \\
To make Jakhilma soft & 9 & 11.7 & 4 & 9 & 12.3 \\
It is traditional system & 7 & 9.1 & 12 & 5 & 6.8 \\
It is readily available & 5 & 6.5 & 24 & 6 & 8.2 \\
Readily available and traditional & 4 & 5.2 & 16 & 28 & 38.4 \\
Cook easily, make Jakhilma soft \& white & 4 & 5.2 & - & - & - \\
It makes thread white & 2 & 2.6 & - & - & - \\
\hline Total & $\mathbf{7 7}$ & $\mathbf{1 0 0}$ & Total & $\mathbf{7 3}$ & $\mathbf{1 0 0}$ \\
\hline
\end{tabular}

\section{Use of kamero mato (Micaceous Clay)}

The farmers use Kamero to make the fibre soft and easier for spinning. It also gives the thread white in colour. The $62.3 \%$ respondents told both purpose of using Kamero. Quantity of Kamero used for one Dharni of dry Lokta also varied from 2 to 16 Mana, however the mean is about 9 Mana. The result is presented in Table 4.

Table 4: Proportion of kamero for one dharni of dry lokta in Mana

\begin{tabular}{ccc}
\hline Proportion & Frequency & Percent \\
\hline 1 & 1 & 1.4 \\
2 & 8 & 10.8 \\
3 & 2 & 2.7 \\
4 & 15 & 20.3 \\
5 & 9 & 12.2 \\
6 & 2 & 2.7 \\
7 & 1 & 1.4 \\
8 & 19 & 25.7 \\
10 & 4 & 5.4 \\
12 & 1 & 1.4 \\
16 & 8 & 10.8 \\
\hline
\end{tabular}

The quality and color of fiber depends upon growing environment in the natural habitat. Dyeing for whitening of fibre is not necessary if Allo is grown under shady and moist places. Washing and cleaning is also easier. From sunny areas, Lokta fibre looks blackish in color and is difficult for washing. But the cloth from its yarn is strong. Lokta can be extracted up to the tip of the stem, but the fiber from upper part is weak.

\section{Spinning}

Women are traditionally involved in spinning using lightweight hand spindles (called Katuwa in Nepali and Wasnam in Rai language) by their men folk. These are about $30-40 \mathrm{~cm}$ long, the shaft is usually made of bamboo and the whorl carved from bone or wood. $94.8 \%$ of respondents used hand spindle. Only about $5 \%$ know about other spinning devices. Such hand spindle is slower than spinning on a wheel device.

Reason for preferring local spindle Katuwa was also assessed. It was understood that majority people prefer Katuwa because it is easy for spinning whilst carrying out other work (Table 5).

\section{Dyeing}

The Allo product makers of the study area have been gradually skilled and commercialized. They produce items according to the client demand. So some of them started to dye the thread and weave fashionable materials. In response to the query, $26.7 \%$ farmers found practicing to dye thread and cloths, while others still had not practiced at all. Dyeing of yarn is done with different plant products for making different colours. The locally available plants are Banmara to make light green or grey colour, Majitho for red, Dar for brown and Dudbilo to make light yellow colour. Dyes are prepared using bark and/or leaf of these plants with different proportion of copper sulphate, ferrous sulphate and potassium dichromate, which were made available by an NGO, Eco-Himal during training.

Table 5: Reasons for preferring hand spindle by farmers

\begin{tabular}{lcc}
\hline Reasons & Frequency & $\mathbf{\%}$ \\
\hline It can be used while walking and shepherding & 56 & 74.7 \\
It is traditional and no idea about other & 13 & 17.3 \\
It makes better quality of thread & 3 & 4.0 \\
It can be used while walking, shepherding and makes quality thread & 2 & 2.7 \\
It can be used while walking, shepherding and no idea about other & 1 & 1.3 \\
\hline Total & $\mathbf{7 5}$ & $\mathbf{1 0 0}$ \\
\hline
\end{tabular}




\section{Weaving and knitting}

Weaving is done in locally made wooden handloom. One can weave 2-2.5 $\mathrm{m}$ of cloth per day if everything is ready. Knitting is being popular due to its high demand. Hand knitting of Shawls, vests and other items by women found while walking for their farm work and by school girls while they go to and come from the school.

\section{Marketing}

Marketing of Allo products is generally done as per demand locally in the country and from abroad. Some products are exported to foreign country like UK, Germany and USA etc. For the knitted products like shawls, vests and others have markets in other countries.

Marketing of products from the study area done through Allo club and co-operatives formed in the villages. Eco-Himal and other NGOs had supported the farmers of Benchhong buying Allo products and timely giving the payment. Price of Allo cloth in the club and co-operative was NRs. 160-200 per meter. The thread is marketed locally at Rs. $600-800$ per Dharni based on quality and location. Fine thread costs higher. A lorry of thread costs Rs. 5 to 10 based on the size. One shawl costs NRs. $400-600$ as per quality and size.

\section{Conclusion and recommendations}

Allo works traditionally started to fulfill the household needs around 1950 has gradually transferred into commercial enterprise after 1984. The exploitation rate of Allo in the study area has been affecting availability and sustainability of raw material in the natural habitat. The situation indicates need of sustainable management through domestication and proper harvesting technique. Need of introducing cost effective processing techniques and improved spinning and weaving methods have been realized.

Allo has become a major raw material for cottage industry in the remote areas like Bala, Sisuwa, Tamku, Mangtewa, Yaphu VDCs of Sankhuwasabha district. It grows naturally and can grow in upper mid to lower belt of high hills (1200 to $3000 \mathrm{~m}$ ) having partial shade, black fertile soil, west and east aspects. There is gradual decline of Allo production in areas, where over-harvested without considering regeneration. The situation is alarming/ demanding for sustainable harvesting and cultivation in the study area.
Extraction of bast and its processing method for quality yarn and thread is difficult, tedious, labor intensive and has low profit margin for the farmers. Despite this, different products are sold in local bazaar, Mela and to the buyers of Kathmandu in reasonable prices.

The users applied local skill and materials for processing, spinning and weaving. There is need of improved processing technique for cost effective and environmental points of views. Traditional knowledge applied for income generation by the Rais seems to disseminate in other parts of the country. Exploring marketing channels of overseas markets for fashionable products is necessary to sustain the enterprise and enhance income generation.

Research and development works should focus on domestication, cultivation, regeneration and sustainable harvesting along with appropriate processing and spinning techniques for better utilization of Allo. Research in this line is being continued by ARS Pakhribas. Supporting partners and stakeholders are welcomed.

Indications of declining availability in the natural forests and increasing distances and time needed for collection in the study area suggest that Allo planting will be necessary to meet the rising demand. As Allo cultivation may be combined with community forestry programs as an under-storey crop, we recommend the following research:

- identify different types / varieties of Allo plant and fibre yields.

- Need to know the effects of various growing conditions and harvesting practices on fibre quality and quantity, so that optimum conditions can be employed

- Need to investigate ways in which Allo might usefully find a places within existing farming and forestry system.

Harvesting/ fibre extraction, processing and spinning techniques are still traditional. It is tedious, labour intensive, health hazardous, requires more fuel and affect on forest and soil degradation. Therefore appropriate technology for these purpose needs to be investigated so as to overcome the problems and increase the income generation of the rural communities residing in the remote villages of northern hills of Nepal. 
There is not assured market of produces. Sometime farmers get pay back of their produces even after nine months. According to exporter based at Kathmandu, there is big demand of Allo product that was never fulfilled. It seems that there is problem of appropriate marketing channels, and intermediates need to be identified for strengthening marketing system.

\section{References}

Dunsmore, JR (1987). Crafts, cash and conservation in bigbland Nepal. Community Development Journal $33,1,49-56$.

Dunsmore, JR (1987). KHARDEP. Rural development in the bills of Nepal. Land Resource Study 36. London: LRDC/ Overseas Development Administration.

Dunsmore, JR and Dunsmore S (2000). Identification of potential opportunity for income generation through Himalayan nettle. Preliminary draft report.

Dunsmore, S (1985). The nettle in Nepal: a cottage industry. London: Land Resources Development Centre.

Dunsmore, S (1993). Nepalese textiles. London: British Museum Press.

Friis, I (1981). A Synopsis of Girardinia (Urticaceae), Kew Bulletin. 36(1), 143-157.

Gibbon, D, Joshi YR, Sharan KC, Schultz M, Thapa MB and Upadhayay MP (1988). A study of the agricultural potential of Chheskam Panchayat. Pakhribas Agriculture Centre. Dhankuta.

Gurung, GV (1988). GTZ/DDDP - Allo (Girardinia diversifolia) Consultancy. Field Survey Report.

Harberli, C (1984). Allo (Himalayan Nettle). Small scale and cottage industry sector, Technical Report, Charikot: Integrated Hill Development Project.
Joshi, YR, Neupane RK, Mainali MP and Gurung GB (1989). Feasibility of Allo production in Bala and Sisuwakhola Panchayat. Pakhribas Agriculture Centre. Dhankuta.

Manandhar, NP (1989). Useful wild plants of Nepal. Stuttgart: Franz Steiner Verlag Wiesbaden GMBH.

Rensburg, L van (1987). Journey to the land of Nettle and the Rai. London: Royal society of Arts Design Bursaries Competition Report.

Rensburg, L van (1987). Sankhuwasabha weaving centre; mid term report. Dhankuta: Women's Training Centre.

Shrestha, B (1994). Dye-yielding plants of Nepal. Kathmandu: RECAST.

Shrestha, KP (2000). Identification of potential opportunity for income generation through Himalayan nettle. Trimester Report, HARP PP-48/99.

Shrestha, R and Hoshion, T (1998). Karyomorphological studies in Girardinia diversifolia (Link) Friis (Urticaceae) collected from Nepal. Journal of Japanese Botany 73(3), 125-127.

Singh, SC and Shrestha, R (1987). Extraction and chemical analysis of Himalayan nettle fibre. Kathmandu: RECAST, Research and Industry 32, 259-262.

Singh, SC and Shrestha, R (1989). Observation on ecodemes in Girardinia diversifolia (Link) Friis, (Urticaceae) in Nepal. Pakistan Journal of Botany 21. 185-190.

Sinha, F (1989). Allo nettle processing in Nepal. New Delhi: Economic Development Associates for Intermediate Technology. 